\title{
10. CORRELATION AND COMPARISON OF FOREARC SITES ${ }^{1}$
}

\author{
Shipboard Scientific Party ${ }^{2}$
}

\section{INTRODUCTION}

Three sites were drilled in the forearc basin of the Izu-Bonin Arc (Figs. 1 and 2). A lithologic and graphic summary of each site is presented in Figure 3. This chapter provides general comments as a framework for a comparison of the sites; the reader is directed to the respective site chapters for details (see "Site 787," "Site 792," and "Site 793" chapters, this volume).

\section{BASEMENT AND BASAL SEDIMENTS}

The forearc basement was cored at Sites 792 and 793. At Site 792 , plagioclase-orthopyroxene-clinopyroxene andesites with minor basaltic andesite and dacite form massive flows with intercalated hyaloclastite and breccia layers. At Site 793, the breccias and massive to pillowed flows are mostly clinopyroxene-orthopyroxene basaltic andesites and andesites that belong to a high$\mathrm{Mg}$ series with boninitic affinities. Minor aphyric lavas and clasts belong to a low-Mg series with tholeiitic affinities.

Basement at Sites 792 and 793 is overlain by brecciated rock. At Site 792 , the brecciation appears to be the result of postdepositional hydrothermal alteration of volcanogenic sandstones. At Site 793, the breccia (about $30 \mathrm{~m}$ thick) is composed mainly of angular clasts of plagioclase-orthopyroxene-clinopyroxene andesite of a different composition from the underlying basement. Nevertheless, the poor organization of the breccia suggests local derivation from a submarine volcano or intrabasinal fault scarp.

The sedimentary rocks overlying the basement at Site 793 date from about $31 \mathrm{Ma}$, based on extrapolation of age-depth plots to the top of the basement (Fig. 4). The basal sedimentary strata at Site 792 are probably of similar age. They are biostratigraphically dated as younger than $34 \mathrm{Ma}$, but sedimentation rates cannot be extrapolated to basement because a major unconformity was crossed near 715 mbsf (about $29 \mathrm{Ma}$ ).

\section{OLIGOCENE TURBIDITES (31-27 Ma)}

Sedimentary rocks that overlie the basal breccia and that are older than 27 Ma constitute a thick Oligocene turbidite succession deposited at undecompacted rates of $80-300 \mathrm{~m} / \mathrm{m}$.y. (Figs. 4 and 5). The coarsest Oligocene deposits were recovered from the 28-29-Ma section (all sites) and the pre-30-Ma succession (Site 793 only). Very thick beds of pebbly sandstone and pebble conglomerate with large floating intraclasts and volcanic cobbles were recovered at Sites 792 and 793. Some of these coarsegrained deposits are interpreted as submarine debris-flow deposits.

All three forearc sites have a relatively complete record of sedimentation from 27-29 Ma, but only Site 793 has a good record of sedimentation from 29-31 Ma (Figs. 5 and 6). The older sediments were not reached at Site 787, and they lap out against a thin basal section above a basement high at Site 792. Depo-

\footnotetext{
${ }^{1}$ Taylor, B., Fujioka, K., et al., 1990. Proc. ODP, Init. Repts., 126: College Station, TX (Ocean Drilling Program).

2 Shipboard Scientific Party is as given in the list of participants preceding the
}

centers to the north of Site 792 and to the west of Site 787 have sedimentary sections more than $100 \%$ thicker than at Site 793 . Contemporaneous rates of deposition varied between the sites, so that Site 792 has the thickest $28-29-M a$ record, whereas Sites 787 and 793 have thicker $27-28$-Ma records. This probably reflects space-time variations in subsidence rates as well as spatial shifts in the positions of feeder channels supplying detritus from the Izu-Bonin Arc to the west, and from the outer-arc high that forms the eastern margin of the basin (Fig. 2). Site 792 is closest to the Izu-Bonin Arc, which may account for the significantly thicker 28-29-Ma record there.

\section{UPPER OLIGOCENE-LOWER MIOCENE STRATA}

\section{(27-18 Ma)}

Sedimentation rates dramatically decreased during the latest Oligocene (23.7-27 Ma) to 4-9 m/m.y. at Sites 792 and 793 and to $20-24 \mathrm{~m} / \mathrm{m}$.y. at Site 787 . The deposits are generally fine grained and burrowed, with minor distal turbidites. At Sites 787 and 792 , the claystones and siltstones locally contain $10 \%-30 \%$ nannofossils. This calcareous component is absent at Site 793, possibly because local paleoceanographic variations caused reduced surface productivity and/or increased bottom-water dissolution.

Canyon cutting at Site 787 left no early Miocene sedimentary section. At Sites 792 and 793, claystones and nannofossil claystones that contain up to $60 \%$ nannofossils accumulated at undecompacted rates of $10-13 \mathrm{~m} / \mathrm{m}$.y. between $21-23.7 \mathrm{Ma}$. The overlying, often nannofossil-rich, silty claystones and clayey siltstones accumulated at 5-9 m/m.y. between 18-21 Ma. The carbonate-rich, very fine-grained, condensed sections at Sites 792 and 793 indicate a widespread low flux of volcanogenic detritus to the forearc basin during the early Miocene. In general, the only significant terrigenous component in the sediments is clay.

\section{UPPERMOST LOWER MIOCENE-UPPER MIOCENE STRATA (18-5 Ma)}

The middle and late Miocene record either is punctuated by unconformities (Sites 787 and 792) or was bypassed to reach deeper objectives (Site 793). At least two phases of submarine valley cutting at Site 787 left essentially no Miocene record, except for one core-catcher sample of unknown lithology.

Uppermost lower Miocene and lower middle Miocene (18-15 Ma) strata are only present at Site 793 (Figs. 4 and 6). The vitric siltstones and sandstones and the clayey siltstones with nannofossil-rich intervals record a renewal of arc volcanism beginning at 17-18 Ma. Sedimentation rates varied between 40 and $70 \mathrm{~m}$ / m.y. (Fig. 4).

Sediments of late middle Miocene and late Miocene age were only recovered at Site 792 (Fig. 4), as the equivalent section at Site 793 was not cored and Site 787 was drilled in Aoga Shima Canyon to bypass this section. The sediments consist mainly of strongly burrowed sandy mudstone and muddy sandstone with nannofossil-rich intervals, deposited at undecompacted rates of $20-50 \mathrm{~m} / \mathrm{m}$.y. The disseminated sand and silt grains are mainly brown scoria, clear volcanic glass shards, and volcanic rock fragments. 


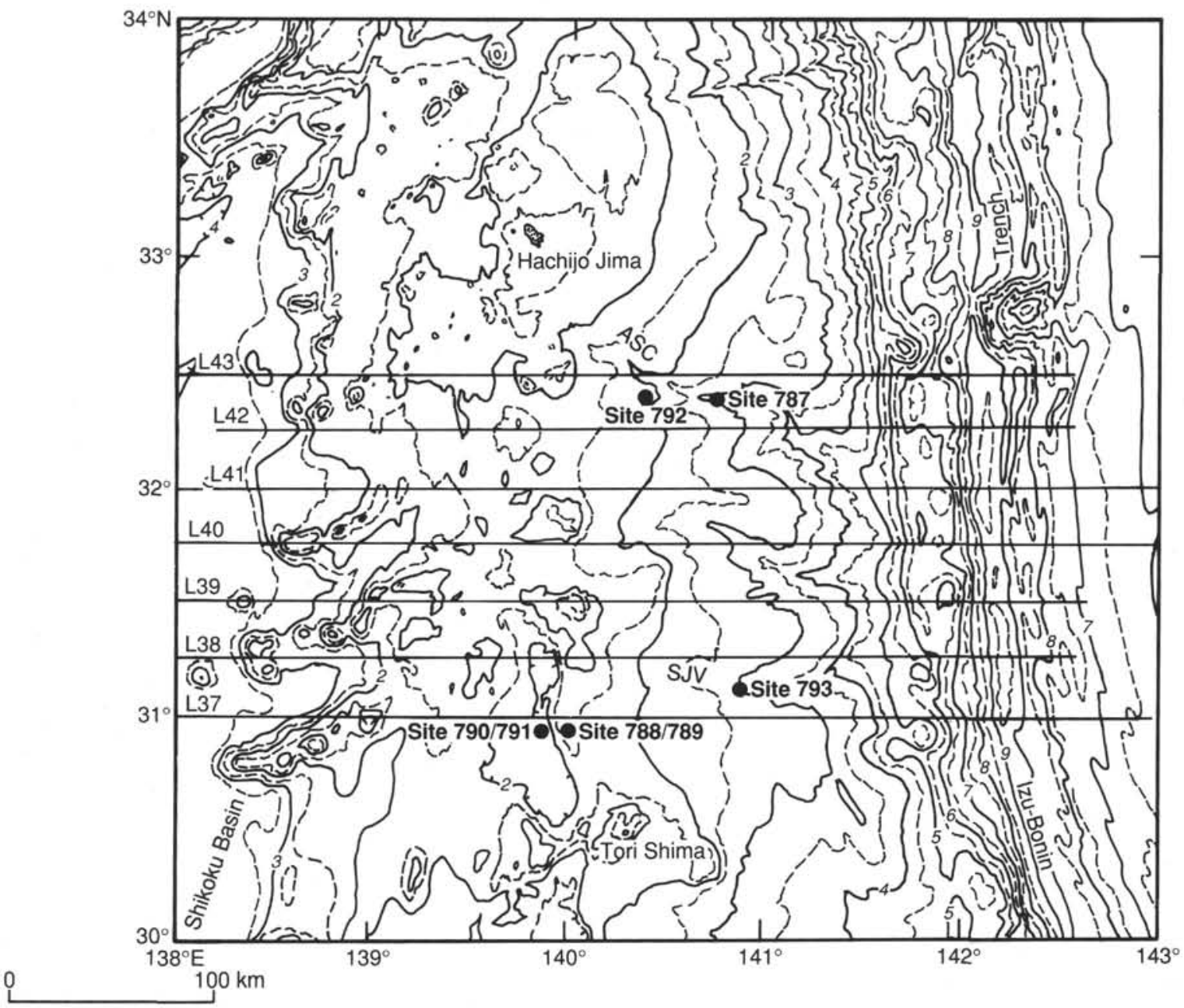

Figure 1. Bathymetric map of the Izu-Bonin Arc between the Shikoku Basin and Izu-Bonin Trench. Leg 126 sites and seismic profiles shown in Figure 2 are indicated; all but Lines 41 and 42 (L41 and L42) end just west of the map boundary in the Shikoku Basin. Bathymetric contour interval is $500 \mathrm{~m}$. Note the positions of Sites 787 and 793 in Aoga Shima Canyon (ASC) and Sumisu Jima Valley (SJV), respectively.

\section{PLIOCENE AND QUATERNARY STRATA (5-0 Ma)}

The Quaternary and Pliocene sections at the three sites vary in their depositional environment, but all reflect a large volcanogenic input. At Sites 787 and 793, sediments of this age were deposited in deep-sea canyons cut into the forearc basin deposits; they consist (in whole or in part) of mixtures of pumiceous and scoriaceous sand and gravel. Drilling at Site 792 recovered a Quaternary and Pliocene fine-grained sedimentary section of predominantly nannofossil-rich, clayey silt and silty clay, punctuated by graded beds of vitric silt, vitric sand, and minor scoriaceous and pumiceous gravel that are interpreted as primary or resedimented volcanic ash.

\section{STRUCTURAL FEATURES}

All sedimentary rocks in the forearc basin that are older than 15 Ma contain a range of extensional features: (1) normal faults and microfaults; (2) steeply dipping fractures that may contain minerals like gypsum or injected sediment; and (3) subvertical, locally kinked dewatering veinlets like those described from the Middle America Trench slope by Ogawa and Miyata (1985) and from the Japan Trench by Arthur et al. (1980) and Lundberg and Leggett (1986). These latter structures are inferred to be the expression of a spaced cleavage that formed during early dewa- tering of unlithified, wet, muddy sediments (Ogawa and Miyata, 1985).

The Izu-Bonin forearc basin did not form until the mid-Oligocene. It is bounded to the east by Eocene volcanic rocks, which crop out on the Bonin Islands and were drilled at $31^{\circ}-$ $32^{\circ} \mathrm{N}$ (Fryer, Pearce, Stokking, et al., 1989). Basement to the west of the basin is also Eocene in age, as determined from the ages of rocks dredged from the frontal-arc high (M. Yuasa, pers. comm.) and the remnant arc (Kyushu-Palau Ridge; Shiki et al., 1985). Eocene margins to the Oligocene forearc basin suggest that the basin originated as an intra-arc rift (see "Site 793" chapter, this volume). Rifting can also explain the extensional structures that characterize the Oligocene section. Extensional microfaulting in the forearc continued into the Miocene, during the time of backarc spreading in the Shikoku Basin (25$15 \mathrm{Ma}$ ). Multichannel seismic profiles indicate that the center of the forearc basin is little faulted after $15 \mathrm{Ma}$, but that in the inner part of the forearc basin even the Pliocene-Pleistocene section is cut by normal faults (Taylor et al., this volume).

\section{REFERENCES}

Arthur, M. A., Carson, B., and von Huene, R. 1980. Initial tectonic deformation of hemipelagic sediment at the leading edge of the Japan convergent margin. In Langseth, M., Okada, H., et al., Init. Repts. 
DSDP, 56, 57, Pt. 1: Washington (U.S. Govt. Printing Office), 569613.

Fryer, P., Pearce, J., Stokking, L. B., et al., 1990. Proc. ODP, Init. Repts., 125: College Station, TX (Ocean Drilling Program).

Honza, E., and Tamaki, K. 1985. The Bonin Arc. In Nairn, A.E.M., Stehli, F. G., and Uyeda, S. (Eds.), The Ocean Basins and Margins, (Vol. 7A): New York (Plenum), 459-502.

Lundberg, N., and Leggett, J. K., 1986. Structural features in cores from the slope landward of the Japan Trench, Deep Sea Drilling Project Leg 87B. In Kagami, H., Karig, D. E., et al., Init. Repts. DSDP, 87: Washington (U.S. Govt. Printing Office), 809-826.
Ogawa, Y., and Miyata, Y., 1985. Vein structure and its deformation history in the sedimentary rocks of the Middle America Trench slope off Guatemala, Deep Sea Drilling Project Leg 84. In von Huene, R., Aubouin, J., et al., Init. Repts. DSDP, 84: Washington (U.S. Govt. Printing Office), 811-829.

Shiki, T., Mizuno, A., and Kobayashi, K., 1985. Data listing of the bottom materials dredged and cored from the Northern Philippine Sea. In Shiki, T. (Ed.), Geology of the Northern Philippine Sea: (Tokai Univ. Press), 23-41.

\section{Ms 126A-111}

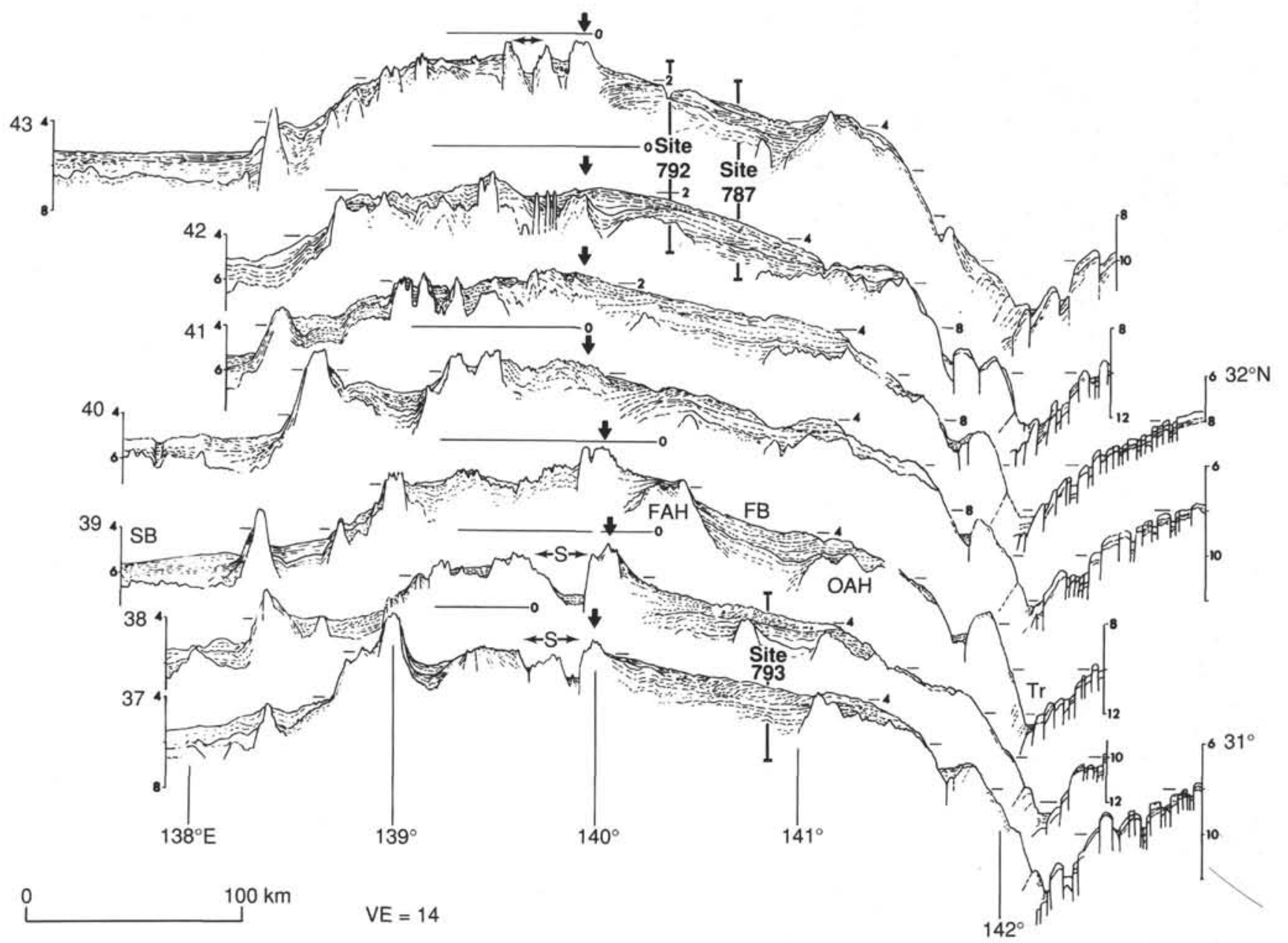

Figure 2. Seven line drawings of east-west, single-channel air-gun records across the Izu-Bonin Arc between latitudes $31^{\circ}$ and $32^{\circ} 30^{\prime} \mathrm{N}$, from Honza and Tamaki (1985). The seismic lines are located in Figure 1. Sites 787, 792, and 793 are located between lines, as indicated. The vertical scale is two-way traveltime (s). The sea surface is indicated by a horizontal line labeled with $0 \mathrm{~s}$ of two-way traveltime. Abbreviations, from east to west, are: $\mathrm{Tr}=$ trench; $\mathrm{OAH}=$ outer-arc basement high; $\mathrm{FB}=$ forearc basin; $\mathrm{FAH}=$ frontal-arc high; $\mathrm{S}=\mathrm{Sumisu}$ Rift; $\mathrm{SB}=\mathrm{Shikoku}$ Basin. Vertical arrows locate the modern volcanic front. 


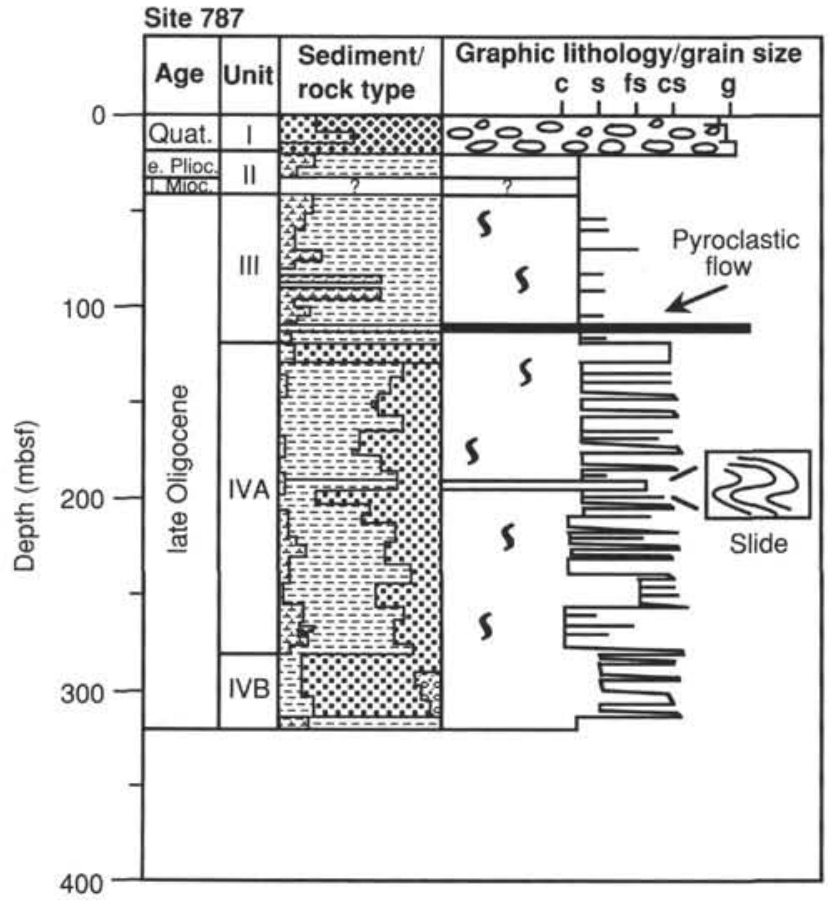

Key to sediment type

\begin{tabular}{|c|c|}
\hline$x$ & Nannofossils \\
\hline & Silt/siltstone and clay/claystone \\
\hline & Vitric and pumiceous sand/sandstone \\
\hline & Pumiceous gravel \\
\hline 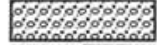 & Conglomerate \\
\hline & Volcanic-clast breccia \\
\hline$\because$ & Lapilli tuff \\
\hline & Andesitic pyroclastics \\
\hline & Andesitic lavas \\
\hline
\end{tabular}

Key to graphic lithology

\begin{tabular}{|c|c|}
\hline 5555 & Bioturbation \\
\hline $0 \cdot 0$ & Sedimentary intraclasts \\
\hline$\because \vdots$ & Volcanic pebbles and cobbles \\
\hline$-\Delta \Delta$ & Andesite fragments \\
\hline & Massive flow \\
\hline
\end{tabular}

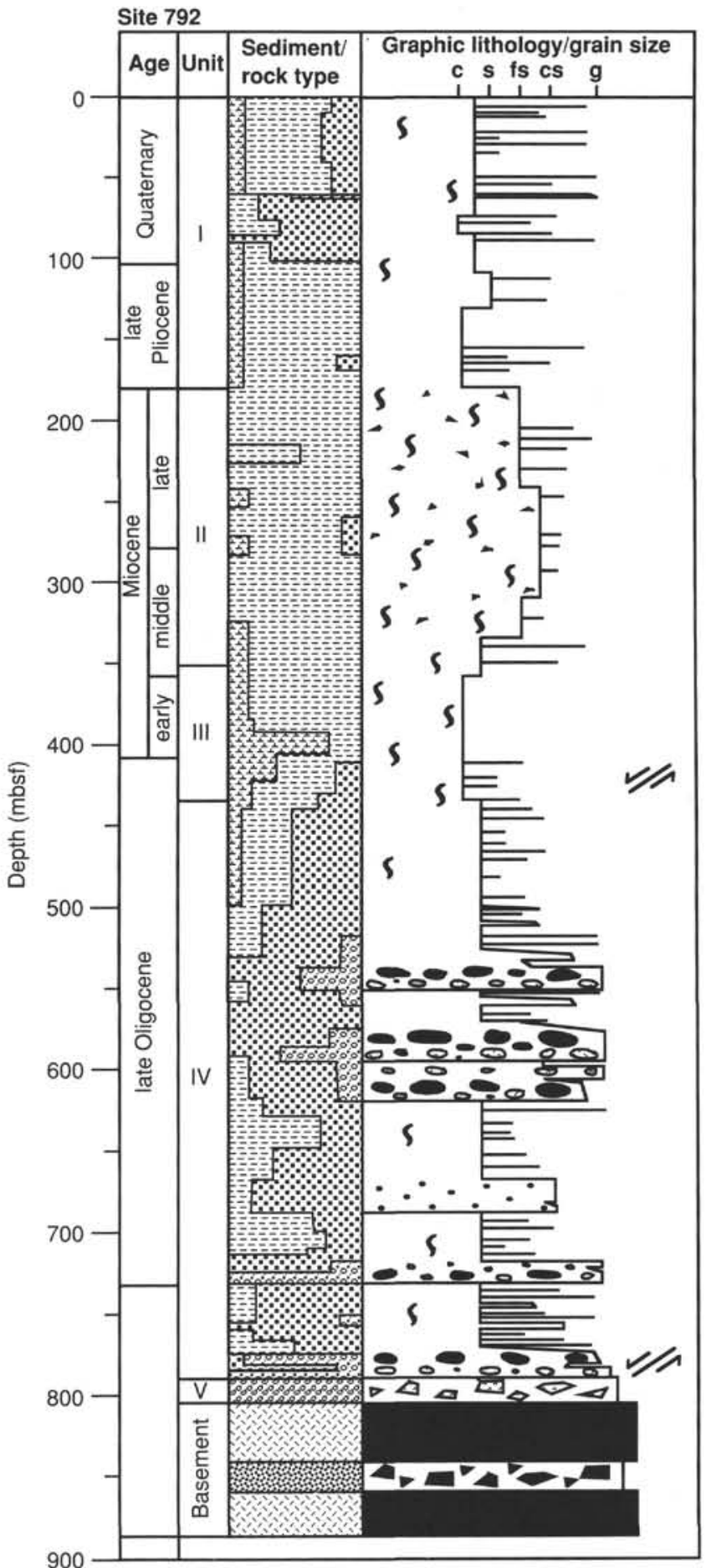

Figure 3. Summary columns for forearc sites, showing depth (mbsf), age, lithologic units, sediment/rock type, and graphic lithology/grain size ( $\mathrm{c}=$ clay/claystone, $\mathrm{s}=$ silt/siltstone, $\mathrm{fs}=$ fine-grained sand/sandstone, $\mathrm{cs}=$ coarse-grained sand/sandstone, and $\mathrm{g}=\mathrm{gravel} / \mathrm{conglomerate}$ ). 

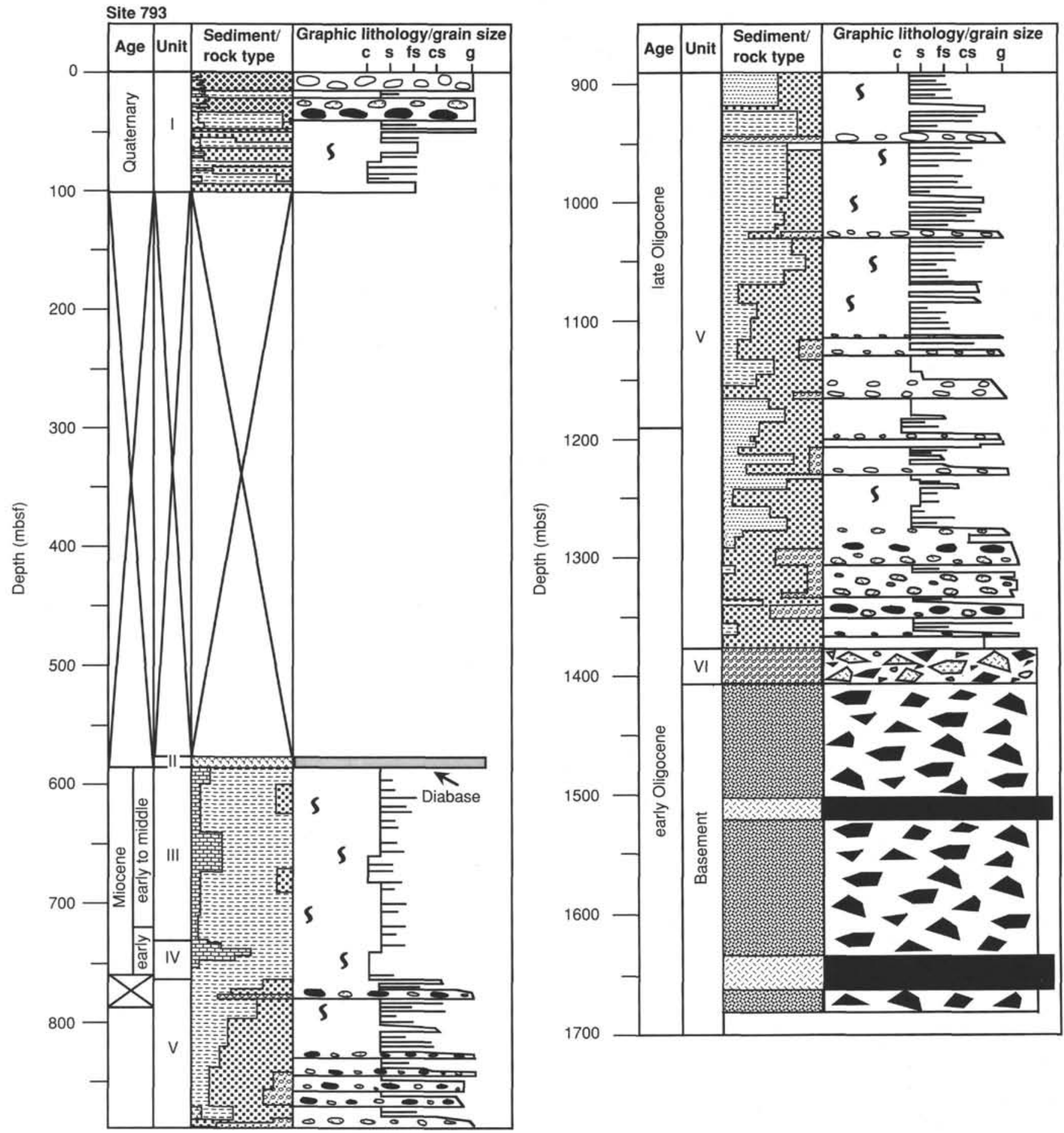

Figure 3 (continued). 


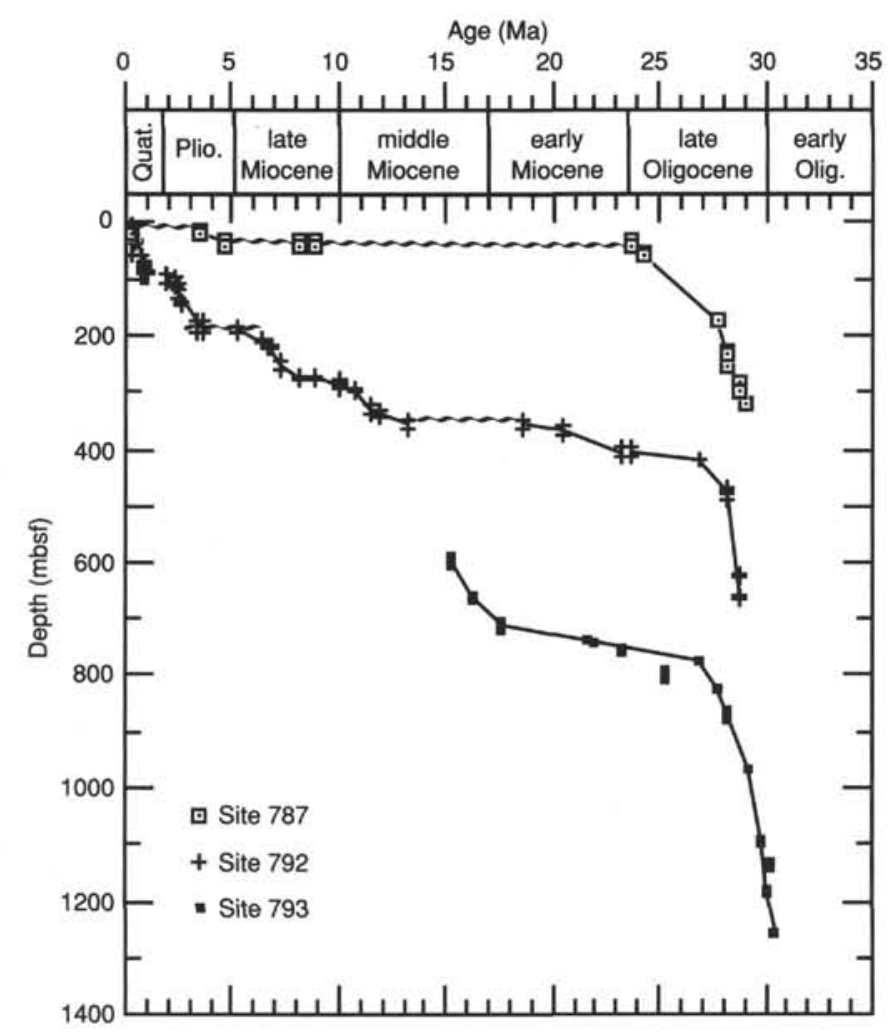

Figure 4. Age-depth plots for forearc sites, with inferred unconformities indicated by wavy lines. Raw data are tabulated in each of the site chapters.

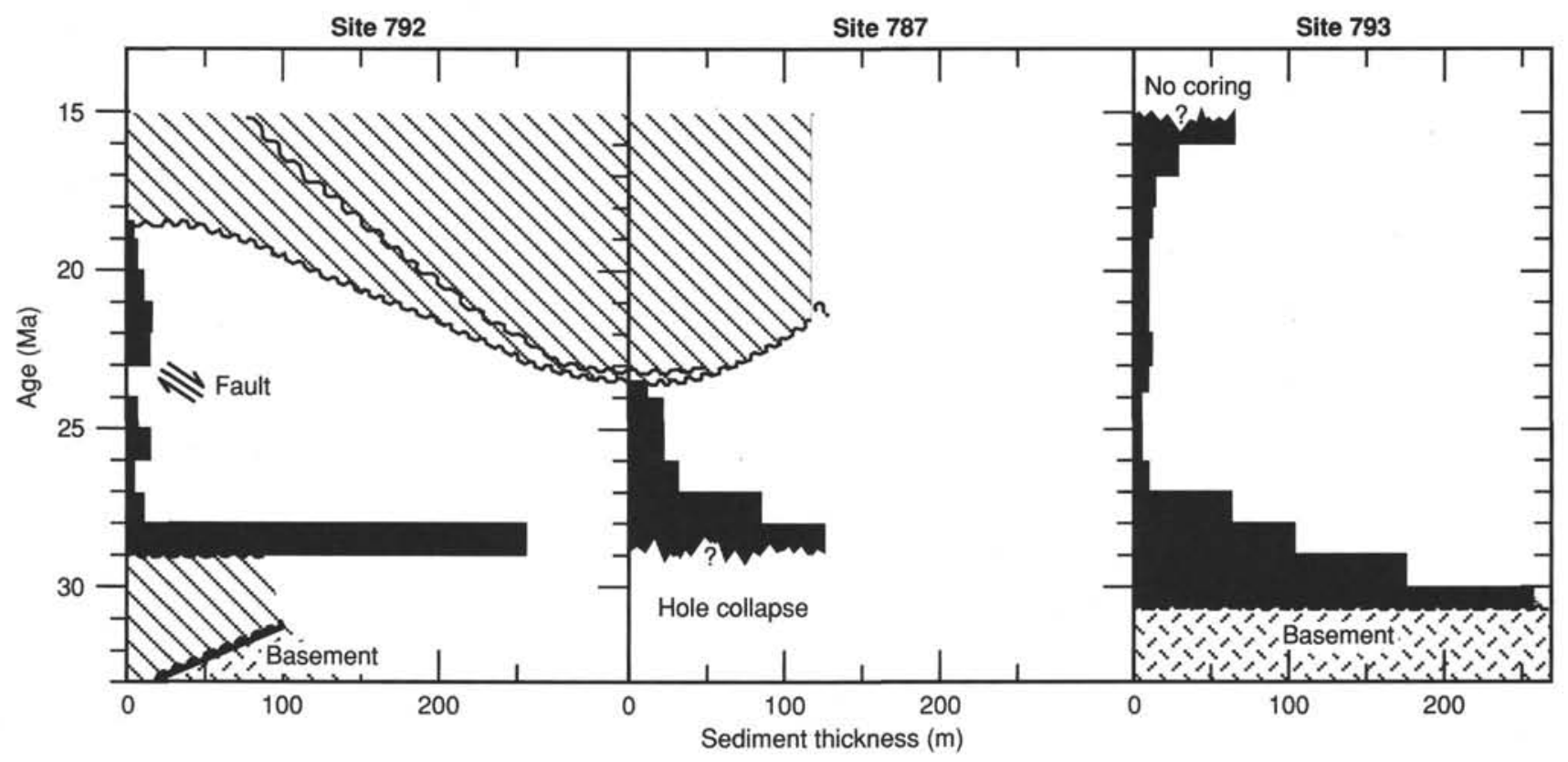

Figure 5. Histograms of undecompacted sediment thickness in each 1-m.y. interval before 15 Ma, determined from age-depth curves (Fig. 4). Hiatuses are indicated by hatched areas. 


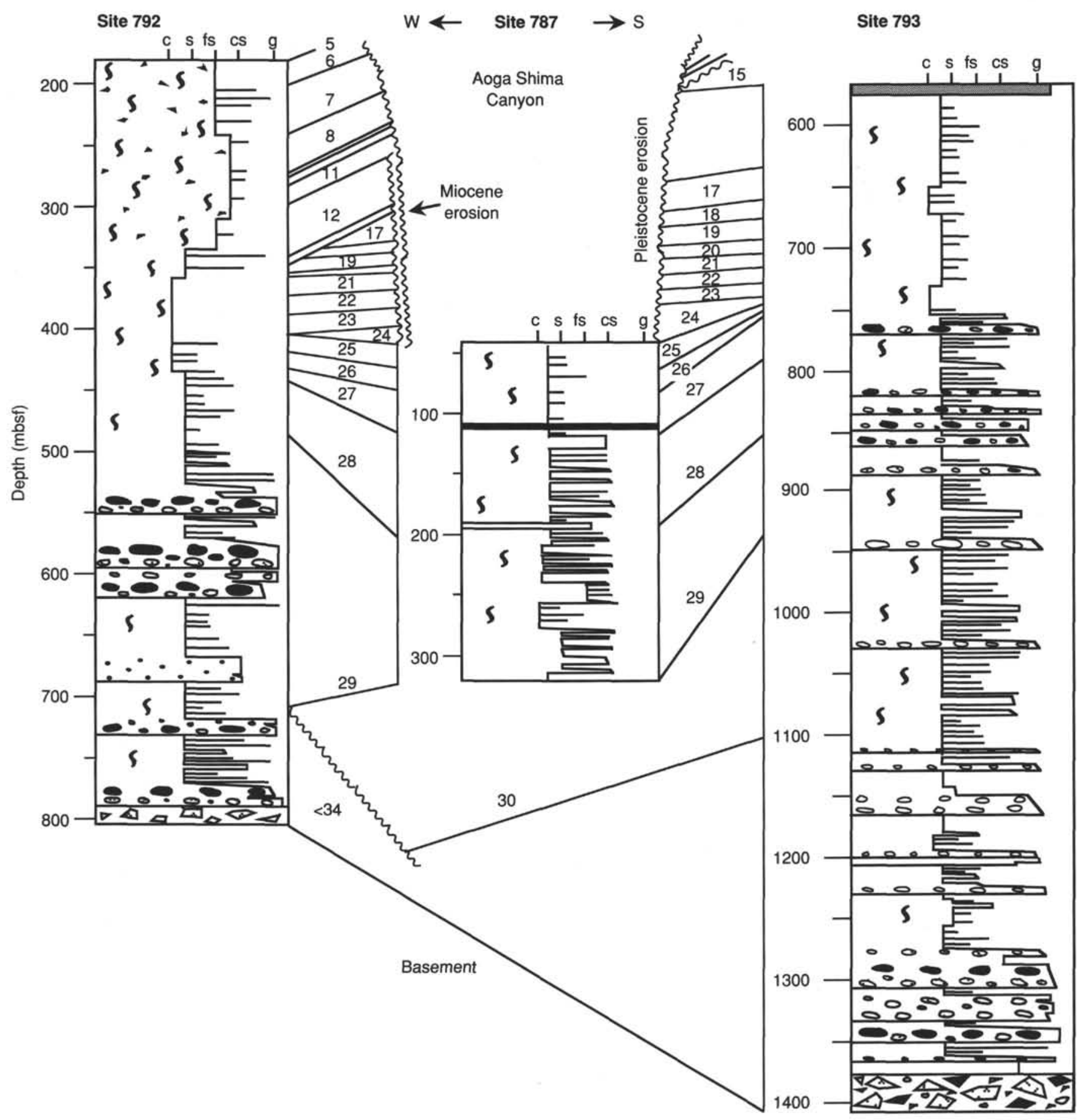

Figure 6. Time lines (at 1-m.y. intervals) joining horizons of equal age at Sites 787, 792, and 793. Ages are determined from age-depth curves (Fig. 4). The arrangement in the figure allows easy comparison of adjacent sites (Sites 787 and 792 and Sites 787 and 793 ) located in the central part of the forearc basin (Fig. 2). The legend is the same as in Figure 3. 